\title{
Nonmotor comorbidities and somatic manifestations of Duchenne Muscular Dystrophy
}

Citation for published version (APA):

Lionarons, J. M. (2021). Nonmotor comorbidities and somatic manifestations of Duchenne Muscular Dystrophy: From a translational neuroscience perspective. [Doctoral Thesis, Maastricht University]. Maastricht University. https://doi.org/10.26481/dis.20210709jl

Document status and date:

Published: 01/01/2021

DOI:

10.26481/dis.20210709jl

Document Version:

Publisher's PDF, also known as Version of record

\section{Please check the document version of this publication:}

- A submitted manuscript is the version of the article upon submission and before peer-review. There can be important differences between the submitted version and the official published version of record.

People interested in the research are advised to contact the author for the final version of the publication, or visit the DOI to the publisher's website.

- The final author version and the galley proof are versions of the publication after peer review.

- The final published version features the final layout of the paper including the volume, issue and page numbers.

Link to publication

\footnotetext{
General rights rights.

- You may freely distribute the URL identifying the publication in the public portal. please follow below link for the End User Agreement:

www.umlib.nl/taverne-license

Take down policy

If you believe that this document breaches copyright please contact us at:

repository@maastrichtuniversity.nl

providing details and we will investigate your claim.
}

Copyright and moral rights for the publications made accessible in the public portal are retained by the authors and/or other copyright owners and it is a condition of accessing publications that users recognise and abide by the legal requirements associated with these

- Users may download and print one copy of any publication from the public portal for the purpose of private study or research.

- You may not further distribute the material or use it for any profit-making activity or commercial gain

If the publication is distributed under the terms of Article $25 \mathrm{fa}$ of the Dutch Copyright Act, indicated by the "Taverne" license above, 


\section{SUMMARY}

Duchenne muscular dystrophy (DMD) is a dystrophinopathy that not solely affects striated muscle tissue. Rather, comorbidities from organs such as the bladder, intestine and brain, suggest involvement of dystrophin in other tissue types. Though there is a great impact of these comorbidities on daily life functioning, ${ }^{1,2}$ there is as yet no standard screening or specific treatment available. Consequently, these comorbidities often remain unrecognized, untreated and their underlying pathophysiological mechanisms unresolved. Determining the role that specific dystrophin isoforms may play in these comorbidities may be instrumental for future standards of care. This thesis aims to provide insights into the origin of comorbidities in DMD, particularly those that involve the bladder, the bowel and the brain. To this end, various methods were applied in preclinical and clinical studies, including immunohistochemistry, Western blot, quantitative polymerase chain reaction [qPCR] and diffusion tensor imaging [DTI]. In addition, existing symptomatic treatments (corticosteroids and methylphenidate) were evaluated that are commonly used in DMD, but do not target dystrophin in specific. Below, a summary of the chapters of this thesis is presented, followed by a general discussion and future perspectives highlighting some caveats and targets for future research on comorbidities in DMD.

\section{Part 1. Introduction}

Chapter 1 is a general introduction of DMD and its clinical characteristics. It furthermore describes the various comorbidities, including their symptomatology and disease course with special attention to the recent changes in care. Consequently, it underscores a lack of knowledge on the pathophysiology underlying comorbidities that occur during aging. Another discussed caveat is that of optimizing screening and treatment for comorbidities. These topics outline the construct of this thesis. This thesis mainly focuses on providing insights into the origin of comorbidities in DMD. It is hypothesized that the dystrophin isoform that is affected and its tissue-specific expression play a role in the occurrence and severity of these specific comorbidities in DMD.

\section{Part 2. Exploring bladder and bowel dysfunction in DMD from a translational neuroscience perspective}

Chapters 2 and 3 evaluate the histological and cellular distribution (immunohistochemistry) and expression (Western blot and qPCR) of multiple dystrophin isoforms in normal nonstriated muscle tissue of rat bladder (chapter 2) and rat intestine (chapter 3). Distribution patterns were evaluated in bladder, duodenum, jejunum, ileum, caecum, colon and rectum tissue from naive, 24-h- and six-months-old Sprague Dawley rats. Immunohistochemical analysis showed dystrophin expression in smooth muscle cells and nerve fibers in the bladder, and in smooth muscle cells and myenteric neurons in the intestine, irrespective of age. The 
bladder of both, neonatal and adult animals, expressed two to three times more Dp71 than Dp140. In the intestine, we found an upregulation of smooth muscle marker alpha-smooth muscle actin, yet Dp71 was equally expressed at both ages. Regionally, Dp71 was expressed predominantly in the distal part of the intestine. These finding of not solely myogenic, but also neurogenic dystrophin expression in the bladder and intestine is interesting in relation to human micturition and gastrointestinal (transit) physiology, and may eventually open a new therapeutic window to treat urological and gastrointestinal comorbidities in pathological conditions, such as DMD.

In Chapter 4, we systematically determined the full extent of bladder and bowel dysfunction $(\mathrm{BBD})$ in patients with DMD ( $\mathrm{n}=57)$, compared with age- and sex-matched healthy controls $(\mathrm{HC}, \mathrm{n}=56)$. To this end, we used the 18-item Childhood Bladder and Bowel Dysfunction Questionnaire (CBBDQ) ${ }^{3}$, which is based on the Rome III criteria ${ }^{4}$ for functional constipation and International Children's Continence Society recommendations. ${ }^{5}$ This survey indicated that $74 \%$ of patients versus $56 \%$ of $\mathrm{HC}$ reported one or more lower urinary tract symptoms (LUTS). Also, 68\% of patients versus 39\% of HC reported one or more bowel symptoms, which constipation being the most prominent bowel dysfunction. Only $5 \%$ of patients was seen or treated by a urologist and $7 \%$ of patients by a gastroenterologist. A negative impact of BBD on daily life functioning was reported in $42 \%$ of patients, and appeared to increase with age. Although constipation appeared to be well recognized and treated, LUTS often remain unrecognized and untreated. These data show that the CBBDQ has added diagnostic value and should therefore be used as a standard screening tool in the multidisciplinary DMD care for all patients, and that regular follow-up is needed as patients grow older.

In Chapter 5, we provide a review of the molecular evidence that implies a role of dystrophin in BBD in DMD through a narrative review from a translational neuroscience perspective. A Pubmed database literature search was conducted to identify the literature describing dystrophin expression in non-striated muscle tissue of rodents and humans. The emphasis of this review is on dystrophin expression in smooth muscle and nervous tissue of the bladder and intestine and its relation to urological and gastrointestinal comorbidities typically seen in DMD. Collectively, these studies suggest that dystrophin expression in smooth muscle and nervous tissue can play a causal role in specific, ageing-related comorbidities, including BBD. The possible biological substrate for dystrophin-associated BBD may differ in relation to the function of these organs, since the bladder predominantly functions as a reservoir for urine and the bowel has an important function in the absorption and excretion of water and electrolytes, which changes during maturation matched with different food intake. Further research is needed using appropriate animal models to unravel the exact pathophysiological mechanisms of these comorbidities. Also, functional evaluation of micturition and intestinal contractility in relation to dystrophin expression should be explored and histopathology can be used to examine the presence, appearance, and density of smooth muscle cells and 
neurons in biopsy material. Finally, additional epidemiology studies on BBD in DMD should include urological and gastrointestinal evaluation, urodynamic and manometric examination and bladder and stool diaries.

\section{Part 3. Evaluating white matter microstructure and psychopharmacotherapy in comorbid neurodevelopmental deficits in Duchenne muscular dystrophy}

In Chapter 6 we address the challenging aspects of linking white matter structures to neurocognitive functioning. Comorbid neurodevelopmental deficits (i.e. attention-deficit hyperactivity disorder [ADHD], autism spectrum disorders [ASD], intellectual disability and specific learning disorders [e.g. reading disabilities]) are common in DMD, but as yet poorly understood. ${ }^{6-8}$ Particularly reading disabilities in general involve an identifiable brain network. To gain a better understanding of the pathophysiology of reading difficulties in DMD, 3D T1-weighted DTI and neuropsychological examination, including a standardized technical reading task ${ }^{9,10}$ were obtained from a total of 40 DMD patients and 29 age- and sex-matched HC. Severe reading difficulties were observed in 10 out of 40 patients and one out of $29 \mathrm{HC}$. Mild reading difficulties were found in 10 out of 40 patients and four out of $29 \mathrm{HC}$. We performed correlation analysis between five reading-related white matter tracts (arcuate fasciculus $[\mathrm{AF}$ ], splenium of the corpus callosum [SPCC], inferior fronto-occipital fasciculus [IFOF], corona radiata [CR] and inferior longitudinal fasciculus [ILF]) and reading performance. Surprisingly, we did not find such a correlation in HC or in patients. We also could not replicate earlier studies that demonstrated a correlation in normal readers. ${ }^{11-13}$ However, the scientific evidence for a correlation is conflicting in normal and dyslectic readers. ${ }^{14}$ Therefore, our results in DMD patients are in line with some of the negative studies that were published. ${ }^{15-17}$ Thus, the pathophysiology of reading deficits in DMD remains elusive. Future studies should increase the sample size with a smaller age range to more reliably assess potential DTI effects. Another method would be to perform more specific and longitudinal measurements, e.g. task-based functional MRI or a more extensive neuropsychological evaluation and assessment of reading performance in combinations with neuropathological examinations.

In Chapter 7, we evaluated the effect of short-acting methylphenidate in DMD patients with comorbid ADHD and stagnating learning performances. Neurocognitive data and data on behavioral and medical functioning, and medical data on disease status, cardiac status and medication interactions were collected from a sample of 10 DMD patients. These data were analyzed in retrospect at baseline (T0, without methylphenidate), short-term follow-up (T1, with methylphenidate; mean treatment duration T0-T1 8.3 months) and long-term follow-up (T2, with methylphenidate; mean treatment duration T1-T2 23.1 months). At T2, seven DMD patients showed considerable improvement in attention. No major side effects were reported in this cohort. Based on this study, regular cardiac follow-up and close monitoring of side effects and neuropsychological effects is recommended. In conclusion of 
part 3 of this thesis, the origin of comorbid neurodevelopmental deficits in DMD unclear. It remains ambiguous if distinct with matter tracts can reliably be correlated to a complex and multifactorial cognitive function, such as reading in general. But especially in DMD, as the brain is diffusely affected by dysfunctional dystrophin expression. And even though, methylphenidate treatment is not targeted to dystrophin in specific, we still observed that it can be clinically effective in patients with DMD and a comorbid ADHD diagnosis. Overall, our findings suggest that neurodevelopmental deficits cannot solely be ascribed to a lack of dystrophin in the brain. Determining if there is a causal role for dystrophin in the neurocognitive profile of patients with DMD remains to be studied.

\section{Part 4. Assessment of nonmotor comorbidities and somatic manifestations of Duchenne muscular dystrophy using the experience sampling method}

Chapter 8 describes a pilot study in eight patients with DMD using the Experience Sampling Method (ESM) to evaluate somatic, cognitive and behavioral side effects of intermittent prednisone use. The ESM is an innovative method to collect daily functioning, behavioral and psychological data by using a smartphone application. This data can assess specific symptoms and contextual factors (i.e. place, company of others and activities) at random moments in daily life. In three consecutive treatment periods (without/with/without prednisone conditions) repeated during four-days per prednisone condition, we evaluated ESM user-friendliness, compliance and its ability to objectify the fluctuations in symptoms that are accompanied by the intermittent prednisone treatment.

No disturbance of normal daily activities or mood was reported and the ESM was evaluated as convenient and user-friendly. However, compliance rates were overall low and decreased with successive prednisone treatment periods from the first to the last four-day assessment period. Previous studies on compliance rates of the ESM showed better compliance when intervals between successive evaluation periods were longer and with fewer evaluations a day. ${ }^{18}$ Because this study included relatively short intervals between periods also during school times, this might have affected compliance. The number of evaluations was, however, already lower in this study (seven evaluations a day) than usual (10 evaluations a day), and should preferably not drop below six to reliably assess diurnal fluctuations. ${ }^{19}$ Nevertheless, the ESM proved to be sensitive to capture extensive fluctuations in symptom severity associated with intermittent prednisone treatment. We found decreased pain and increased distraction levels and insecurity in relation to prednisone use. These findings support previous literature on steroids as pain relief adjuvants and steroid-related central nervous system side effects. ${ }^{20,21}$ 


\section{LITERATURE}

1. van Wijk E, Messelink BJ, Heijnen L, de Groot IJ. Prevalence and psychosocial impact of lower urinary tract symptoms in patients with Duchenne muscular dystrophy. Neuromuscul Disord 2009;19:754-758.

2. Pangalila RF, van den Bos GA, Bartels B, Bergen M, Stam HJ, Roebroeck ME. Prevalence of fatigue, pain, and affective disorders in adults with duchenne muscular dystrophy and their associations with quality of life. Arch Phys Med Rehabil 2015;96:1242-1247.

3. van Engelenburg-van Lonkhuyzen ML, Bols EM, Bastiaenen CH, Benninga MA, de Bie RA. Childhood bladder and bowel dysfunction questionnaire: development, feasibility, and aspects of validity and reliability. Journal of pediatric gastroenterology and nutrition 2017;64:911-917.

4. Drossman DA, Dumitrascu DL. Rome III: New standard for functional gastrointestinal disorders. Journal of Gastrointestinal and Liver Diseases 2006;15:237.

5. Austin PF, Bauer SB, Bower W, et al. The standardization of terminology of lower urinary tract function in children and adolescents: Update report from the standardization committee of the International Children's Continence Society. Neurourology and urodynamics 2016;35:471-481.

6. Hendriksen JG, Vles JS. Neuropsychiatric disorders in males with duchenne muscular dystrophy: frequency rate of attention-deficit hyperactivity disorder (ADHD), autism spectrum disorder, and obsessive-compulsive disorder. J Child Neurol 2008;23:477-481.

7. Pane M, Scalise R, Berardinelli A, et al. Early neurodevelopmental assessment in Duchenne muscular dystrophy. Neuromuscul Disord 2013;23:451-455.

8. Ricotti V, Mandy WP, Scoto M, et al. Neurodevelopmental, emotional, and behavioural problems in Duchenne muscular dystrophy in relation to underlying dystrophin gene mutations. Dev Med Child Neurol 2016;58:77-84.

9. Van den Bos K, Lutje Spelberg H. Continu benoemen \& woorden lezen. Een test voor het diagnosticeren van taal-en leesstoornissen Handleiding Amsterdam: Boom Testuitgevers 2007.

10. Torgesen JK, Rashotte CA, Wagner RK. TOWRE: Test of word reading efficiency: Psychological Corporation Toronto, Ontario, 1999.

11. Vandermosten M, Boets B, Poelmans H, Sunaert S, Wouters J, Ghesquiere P. A tractography study in dyslexia: neuroanatomic correlates of orthographic, phonological and speech processing. Brain 2012;135:935948.

12. Lou C, Duan X, Altarelli I, Sweeney JA, Ramus F, Zhao J. White matter network connectivity deficits in developmental dyslexia. Hum Brain Mapp 2019;40:505-516.

13. Zhang $M$, Chen $C$, Xue G, et al. Language-general and -specific white matter microstructural bases for reading. Neuroimage 2014;98:435-441.

14. Vandermosten M, Boets B, Wouters J, Ghesquière P. A qualitative and quantitative review of diffusion tensor imaging studies in reading and dyslexia. Neuroscience \& Biobehavioral Reviews 2012;36:1532-1552.

15. Beaulieu C, Plewes C, Paulson LA, et al. Imaging brain connectivity in children with diverse reading ability. Neuroimage 2005;25:1266-1271.

16. Niogi SN, McCandliss BD. Left lateralized white matter microstructure accounts for individual differences in reading ability and disability. Neuropsychologia 2006;44:2178-2188.

17. Carter JC, Lanham DC, Cutting LE, et al. A dual DTI approach to analyzing white matter in children with dyslexia. Psychiatry Res 2009;172:215-219.

18. Vachon H, Viechtbauer W, Rintala A, Myin-Germeys I. Compliance and Retention With the Experience Sampling Method Over the Continuum of Severe Mental Disorders: Meta-Analysis and Recommendations. Journal of medical Internet research 2019;21:e14475. 
19. Verhagen SJ. The power of individual landscapes: a clinical exploration of personal experience sampling and new horizons. 2020.

20. Vyvey M. Steroids as pain relief adjuvants. Can Fam Physician 2010;56:1295-1297, e1415.

21. Ciriaco M, Ventrice P, Russo G, et al. Corticosteroid-related central nervous system side effects. J Pharmacol Pharmacother 2013;4:S94-98. 


\section{SAMENVATTING}

Duchenne spierdystrofie (DMD) is een dystrophinopathie die niet alleen dwarsgestreept spierweefsel aantast. Comorbiditeiten die betrekking hebben op organen als de blaas, darmen of het brein, wekken eerder de suggestie dat dystrofine ook betrokken is in andere typen weefsels. Hoewel deze comorbiditeiten van grote invloed zijn op het dagelijks functioneren, ${ }^{1,2}$ is er tot nu toe nog geen standaard screening of specifieke behandeling hiervoor beschikbaar. Ten gevolge hiervan, worden deze comorbiditeiten vaak niet herkend, onder behandeld en blijven de onderliggende pathofysiologische mechanismes onopgelost. Het bepalen van de rol die specifieke dystrofine isoformen zouden kunnen hebben in deze comorbiditeiten kan instrumenteel zijn voor de toekomstige zorgstandaard.

Het doel van dit proefschrift is om inzicht te krijgen in de origine van comorbiditeiten in DMD, in het bijzonder die betrekking hebben op de blaas, darmen en het brein. Hiertoe zijn verscheidene methoden toegepast in preklinsche en klinische studies, waaronder immunohistochemie, Western blot, quantitative polymerase chain reaction [qPCR] en diffusion tensor imaging [DTI]. In aanvulling hierop zijn er bestaande symptomatische behandelingen (corticosteroïden en methylfenidaat) geëvalueerd die over het algemeen worden gebruikt bij DMD, maar die niet specifiek gericht zijn op dystrofine.

\section{Deel 1. Introductie}

Hoofdstuk 1 is een algemene introductie van DMD en de klinische karakteristieken ervan. Bovendien worden de verscheidene comorbiditeiten beschreven, waaronder de symptomatologie en het ziektebeloop met speciale aandacht voor recente veranderingen in de zorg. Derhalve onderstreept dit het gebrek aan kennis over de pathofysiologie die ten gronde ligt aan comorbiditeiten die optreden bij veroudering. Een ander punt van discussie is de optimalisatie van screening en behandeling van deze comorbiditeiten. Deze onderwerpen schetsen de opbouw van dit proefschrift. Dit proefschrift focust op het verkrijgen van inzicht in de origine van comorbiditeiten in DMD. De hypothese is dat dystrofine isoformen die aangedaan zijn en hun weefselspecifieke expressie een rol hebben in het voorkomen en de ernst van deze specifieke comorbiditeiten in DMD.

\section{Deel 2. Het verkennen van blaas en darm dysfunctie in DMD vanuit een translationeel neurowetenschappelijk perspectief}

Hoofdstukken 2 en 3 evalueren de histologische en cellulaire distributie (immunohistochemie) en expressie (Western blot en $q P C R$ ) van meerdere dystrofine isoformen in normaal niet-dwarsgestreept spierweefsel van de rat blaas (hoofdstuk 2) en de rat darm (hoofdstuk 3). Distributie patronen zijn geëvalueerd in weefsel van de blaas, het duodenum, jejunum, ileum, coecum, colon en rectum van naïeve, 24-uur- en zes-maanden-oude Sprague Dawley ratten. Immunohistochemische analyse toonde dystrofine expressie in gladde spiercellen en 
zenuwvezels in de blaas, en in gladde spiercellen en myenterische neuronen in de darm, onafhankelijk van leeftijd. In de blaas van zowel, neonatale als volwassen dieren, kwam twee tot drie keer zoveel Dp71 dan Dp140 tot expressie. In de darmen vonden we een upregulatie van gladde spiercel marker alpha-smooth muscle actin, en toch kwam Dp71 in gelijke mate tot expressie op beide leeftijden. Regionaal kwam Dp71 hoofdzakelijk tot expressie in het distale gedeelte van de darmen. De bevinding van niet alleen myogene, maar ook neurogene dystrofine expressie in de blaas en de darm is interessant in relatie tot de humane fysiologie van mictie en defecatie, en zal uiteindelijk een nieuw therapeutisch venster openen om urologische en gastro-intestinale comorbiditeiten te behandelen in pathologische aandoeningen, zoals DMD.

In Hoofdstuk 4, bepalen we op een systematische manier de gehele reikwijdte van blaas en darm dysfunctie (BBD) in patiënten met DMD ( $\mathrm{n}=57)$, vergeleken met leeftijds- en geslachtsgepaarde gezonde controles $(\mathrm{HC}, \mathrm{n}=56)$. Hiertoe hebben we gebruik gemaakt van de 18-item Childhood Bladder and Bowel Dysfunction Questionnaire $(C B B D Q)^{3}$, die gebaseerd is op de Rome III criteria ${ }^{4}$ voor functionele constipatie en International Children's Continence Society aanbevelingen. ${ }^{5}$ Deze vragenlijst indiceerde dat $74 \%$ van de patiënten versus $56 \%$ van de $\mathrm{HC}$ een of meer lagere urinewegklachten (LUTS) rapporteren. Ook rapporteerden 68\% van de patiënten versus 39\% van de HC een of meer darm symptomen, waarvan constipatie de meest prominentie darm dysfunctie was. Slechts $5 \%$ van de patiënten was/werd gezien of behandeld door een uroloog en $7 \%$ van de patiënten door een gastro-enteroloog. Een negatieve invloed van BBD op het dagelijks functioneren werd gerapporteerd in $42 \%$ van de patiënten, en leek toe te nemen met de leeftijd. Hoewel constipatie goed leek te worden herkend en behandeld, werden LUTS vaak niet herkend of onder behandeld. Deze data laat zien dat de CBBDQ van toegevoegde diagnostische waarde is en daarom als standaard screeninginstrument in de multidisciplinaire DMD zorgstandaard voor alle patiënten zou moeten worden opgenomen, en dat follow-up op reguliere basis nodig is wanneer patiënten ouder worden.

In Hoofdstuk 5, voorzien we van een review over het moleculaire bewijs dat een rol van dystrofine in BBD in DMD impliceert door middel van een beschrijvende review vanuit translationeel wetenschappelijk oogpunt. Een Pubmed database literatuur search is uitgevoerd om de literatuur te identificeren die de expressie van dystrofine beschrijft in nietdwarsgestreept spierweefsel van knaagdieren en mensen. De nadruk van dit review ligt op dystrofine expressie in glad spierweefsel en zenuwweefsel van de blaas en de darmen en de relatie tot urologische en gastro-intestinale comorbiditeiten die typerend zijn in DMD.

Gezamenlijk suggereren deze studies dat dystrofine expressie in glad spierweefsel en zenuwweefsel een oorzakelijke rol kan hebben in specifieke comorbiditeiten die gerelateerd kunnen zijn aan veroudering, waaronder BBD. Het mogelijke biologische substraat voor $\mathrm{BBD}$ die met dystrofine geassocieerd zijn kan verschillen in relatie tot de functie van deze organen. Aangezien de blaas hoofdzakelijk dient als een reservoir voor urine en de darmen 
een belangrijke functie hebben in de absorptie en excretie van water en elektrolyten, die verandert tijdens rijping samen met de verandering in voeding. Nader onderzoek is nodig waarbij gebruikt wordt gemaakt van gepaste diermodellen om de exacte pathofysiologische mechanismen van deze comorbiditeiten te ontrafelen. Ook zal functionele evaluatie van mictie en intestinale contractie in relatie tot dystrofine expressie moeten worden geëxploreerd en de histopathologie kan worden gebruikt om de aanwezigheid, het voorkomen van en de densiteit van gladde spiercellen en neuronen in biopsie materiaal te onderzoeken. Tot slot zullen aanvullende epidemiologische studies over BBD in DMD urologische en gastrointestinale evaluatie, urodynamisch en manometrisch onderzoek en plas- en poepdagboeken moeten includeren.

\section{Deel 3. Evaluatie van de microstructuur van witte stof en psychofarmacotherapie in comorbide neurologische ontwikkelingsstoornissen in Duchenne spierdystrofie}

In Hoofdstuk $\mathbf{6}$ adresseren we de uitdagende aspecten van de koppeling van witte stof structuren aan neurocognitief functioneren. Comorbide neurologische ontwikkelingsstoornissen (i.e. attention-deficit hyperactivity disorder [ADHD], autism spectrum disorders [ASD], zwakbegaafdheid en specifieke leerstoornissen [e.g. leesstoornissen]) zijn veelvoorkomend in DMD, maar tot nu toe slecht begrepen. ${ }^{6-8}$

In het bijzonder is er bij leesstoornissen in het algemeen een identificeerbaar hersennetwerk betrokken. Om de pathofysiologie van leesstoornissen in DMD beter te begrijpen, zijn er 3D T1-gewogen DTI scans en neuropsychologische onderzoek, waaronder een gestandaardiseerde leestaak ${ }^{9,10}$ verworven onder in totaal 40 DMD patiënten en 29 leeftijds- en geslachtsgepaarde HC. Ernstige leesproblemen werden in 10 van de 40 patiënten geobserveerd en een van de 29 HC. Milde leesproblemen werden gevonden in 10 van de 40 patiënten en vier van de $29 \mathrm{HC}$. We hebben een correlatieanalyse uitgevoerd tussen vijf grote witte stofbanen die met leesvermogen zijn geassocieerd (de fasciculus arcuatus [AF], het splenium van het corpus callosum [SPCC], de inferieure fronto-occipitale fasciculus [IFOF], de corona radiata $[\mathrm{CR}]$ en de inferieure longitudinal fasciculus [ILF]) en leesprestatie.

Verrassend genoeg vonden we geen correlatie in $\mathrm{HC}$ of in patiënten. We zijn er ook niet in geslaagd om eerdere studies te repliceren die een correlatie hebben aangetoond in normale lezers. ${ }^{11-13}$ Desalniettemin, is het wetenschappelijke bewijs voor een correlatie tegenstrijdig in normale en dyslectische lezers. ${ }^{14}$ Daarom zijn onze resultaten van de DMD patiënten in lijn met sommige negatieve studies die er zijn gepubliceerd. ${ }^{15-17}$ Hiermee blijft de pathofysiologie van leesstoornissen in DMD ongrijpbaar. Toekomstige studies zouden de steekproefgrootte moeten vergroten met een smallere leeftijdsrange om potentiele DTI effecten op een beter betrouwbare manier te beoordelen. Een andere methode zou kunnen zijn om specifiekere en longitudinale metingen, e.g. task-based functional MRI te doen of een meer uitgebreide neuropsychologische evaluatie en het beoordelen van leesprestatie in combinatie met neuropathologisch onderzoek. 
In Hoofdstuk 7, evalueren we het effect van kortwerkend methylfenidaat in DMD patiënten met een comorbide ADHD en stagnerende leerprestaties. Neurocognitieve data en data van gedragsmatig en medisch functioneren, en medische data over de status van de ziekte, cardiale status en medicatie interacties zijn verzameld van 10 DMD patiënten. Deze data is in retrospect geanalyseerd op baseline (T0, zonder methylfenidaat), korte termijn follow-up (T1, met methylfenidaat; gemiddelde behandelduur T0-T1 8.3 maanden) en lange termijn follow-up (T2, met methylfenidaat; gemiddelde behandelduur T1-T2 23.1 maanden). Op T2, lieten zeven DMD patiënten een aanzienlijke verbetering zien in aandacht. Er zijn geen ernstige bijwerkingen gerapporteerd in dit cohort. Gebaseerd op deze studie wordt cardiale follow-up op reguliere basis en nauwlettende monitoring van bijwerkingen en van neuropsychologische effecten aanbevolen. Concluderend voor deel drie van dit proefschrift, is de origine van comorbide neurologische ontwikkelingsstoornissen in DMD onduidelijk. Het blijft meerduidig of afzonderlijke witte stof banen op een betrouwbare manier gecorreleerd kunnen worden aan een complexe en multifactoriële cognitieve functie, zoals lezen in het algemeen. Maar vooral in DMD, aangezien het brein diffuus is aangedaan door dysfunctionele dystrofine expressie. En hoewel methylfenidaat behandeling niet specifiek gericht is op dystrofine, hebben we geobserveerd dat het alsnog klinisch effectief kan zijn in patiënten met DMD en een cormorbide ADHD diagnose. Al met al suggereren onze bevindingen dat neurologische ontwikkelingsstoornissen niet enkel toegeschreven kunnen worden aan een tekort aan dystrofine in het brein. Het bepalen of er een oorzakelijke rol is voor dystrofine in het neurocognitieve profiel van patiënten met DMD moet nog nader bestudeerd worden.

\section{Deel 4. Beoordeling van nonmotore comorbiditeiten en somatische manifestaties van Duchenne spierdystrofie met behulp van de experience sampling method}

Hoofdstuk 8 beschrijft een pilotstudie in acht patiënten met DMD waarbij gebruik wordt gemaakt van de Experience Sampling Method (ESM) om somatische, cognitieve en gedragsmatige bijwerkingen van intermitterend prednison gebruik te evalueren. De ESM is een innovatieve methode om data te verzamelen over het dagelijks functioneren, gedrag en welbevinden met behulp van een smartphone applicatie. Deze data kan specifieke symptomen en contextuele factoren (i.e. plaats, gezelschap van anderen en activiteiten) op willekeurige momenten in het dagelijks leven vaststellen. In drie opeenvolgende behandelperiodes (met/ zonder/met prednison condities) van vier dagen per prednison conditie, hebben we de gebruikersvriendelijkheid en compliance van ESM geëvalueerd, en het vermogen om fluctuaties in symptomen te objectiveren die gepaard gaan met intermitterende prednison behandeling. Er werden geen verstoringen in normale dagelijkste activiteiten of stemming gerapporteerd en de ESM werd beoordeeld als handig en gebruikersvriendelijk. Desalniettemin was de compliance over het algemeen laag en verminderde deze met opeenvolgende prednison behandelperiodes vanaf de eerste tot de laatste vierdaagse meting. Voorgaande studies over compliance bij de ESM laten betere compliance zien wanneer de intervallen tussen opeen- 
volgende evaluatie perioden langer zijn en met minder evaluaties per dag. ${ }^{18}$ Omdat deze studie relatief korte intervallen tussen de periodes heeft gehanteerd, ook tijdens schooltijd, zou dit de compliance kunnen hebben beïnvloed. Het aantal evaluaties was desondanks al lager in deze studie (zeven metingen per dag) dan normaal (10 metingen per dag), en zou bij voorkeur niet lager moeten zijn dan zes evaluaties om fluctuaties gedurende de dag te kunnen beoordelen. ${ }^{19}$ Desalniettemin, heeft de ESM bewezen sensitief genoeg te zijn om uitgebreide fluctuaties in ernst van symptomen die geassocieerd zijn met intermitterend prednison behandeling vast te leggen. We hebben een vermindering in de ervaring van pijn en een verhoogde afleidbaarheid en gevoelens van onzekerheid gevonden in relatie tot prednisongebruik. Deze bevindingen ondersteunen voorgaande literatuur over steroïden als pijnverlichter en steroïde-gerelateerde bijwerkingen die betrekking hebben op het centrale zenuwstelsel. $^{20,21}$ 


\section{LITERATUUR}

1. van Wijk E, Messelink BJ, Heijnen L, de Groot IJ. Prevalence and psychosocial impact of lower urinary tract symptoms in patients with Duchenne muscular dystrophy. Neuromuscul Disord 2009;19:754-758.

2. Pangalila RF, van den Bos GA, Bartels B, Bergen M, Stam HJ, Roebroeck ME. Prevalence of fatigue, pain, and affective disorders in adults with duchenne muscular dystrophy and their associations with quality of life. Arch Phys Med Rehabil 2015;96:1242-1247.

3. van Engelenburg-van Lonkhuyzen ML, Bols EM, Bastiaenen CH, Benninga MA, de Bie RA. Childhood bladder and bowel dysfunction questionnaire: development, feasibility, and aspects of validity and reliability. Journal of pediatric gastroenterology and nutrition 2017;64:911-917.

4. Drossman DA, Dumitrascu DL. Rome III: New standard for functional gastrointestinal disorders. Journal of Gastrointestinal and Liver Diseases 2006;15:237.

5. Austin PF, Bauer SB, Bower W, et al. The standardization of terminology of lower urinary tract function in children and adolescents: Update report from the standardization committee of the International Children's Continence Society. Neurourology and urodynamics 2016;35:471-481.

6. Hendriksen JG, Vles JS. Neuropsychiatric disorders in males with duchenne muscular dystrophy: frequency rate of attention-deficit hyperactivity disorder (ADHD), autism spectrum disorder, and obsessive-compulsive disorder. J Child Neurol 2008;23:477-481.

7. Pane M, Scalise R, Berardinelli A, et al. Early neurodevelopmental assessment in Duchenne muscular dystrophy. Neuromuscul Disord 2013;23:451-455.

8. Ricotti V, Mandy WP, Scoto M, et al. Neurodevelopmental, emotional, and behavioural problems in Duchenne muscular dystrophy in relation to underlying dystrophin gene mutations. Dev Med Child Neurol 2016;58:77-84.

9. Van den Bos K, Lutje Spelberg H. Continu benoemen \& woorden lezen. Een test voor het diagnosticeren van taal-en leesstoornissen Handleiding Amsterdam: Boom Testuitgevers 2007.

10. Torgesen JK, Rashotte CA, Wagner RK. TOWRE: Test of word reading efficiency: Psychological Corporation Toronto, Ontario, 1999.

11. Vandermosten M, Boets B, Poelmans H, Sunaert S, Wouters J, Ghesquiere P. A tractography study in dyslexia: neuroanatomic correlates of orthographic, phonological and speech processing. Brain 2012;135:935948.

12. Lou C, Duan X, Altarelli I, Sweeney JA, Ramus F, Zhao J. White matter network connectivity deficits in developmental dyslexia. Hum Brain Mapp 2019;40:505-516.

13. Zhang M, Chen C, Xue G, et al. Language-general and -specific white matter microstructural bases for reading. Neuroimage 2014;98:435-441.

14. Vandermosten M, Boets B, Wouters J, Ghesquière P. A qualitative and quantitative review of diffusion tensor imaging studies in reading and dyslexia. Neuroscience \& Biobehavioral Reviews 2012;36:1532-1552.

15. Beaulieu C, Plewes C, Paulson LA, et al. Imaging brain connectivity in children with diverse reading ability. Neuroimage 2005;25:1266-1271.

16. Niogi SN, McCandliss BD. Left lateralized white matter microstructure accounts for individual differences in reading ability and disability. Neuropsychologia 2006;44:2178-2188.

17. Carter JC, Lanham DC, Cutting LE, et al. A dual DTI approach to analyzing white matter in children with dyslexia. Psychiatry Res 2009;172:215-219.

18. Vachon H, Viechtbauer W, Rintala A, Myin-Germeys I. Compliance and Retention With the Experience Sampling Method Over the Continuum of Severe Mental Disorders: Meta-Analysis and Recommendations. Journal of medical Internet research 2019;21:e14475. 
19. Verhagen SJ. The power of individual landscapes: a clinical exploration of personal experience sampling and new horizons. 2020.

20. Vyvey M. Steroids as pain relief adjuvants. Can Fam Physician 2010;56:1295-1297, e1415.

21. Ciriaco M, Ventrice P, Russo G, et al. Corticosteroid-related central nervous system side effects. J Pharmacol Pharmacother 2013;4:S94-98. 